\title{
Clinical Benefits of Biochemical Markers of Fibrosis in Egyptian Children With Chronic Liver Diseases
}

\author{
Tawhida Y. Abdel-Ghaffar ${ }^{\mathrm{a}}$, Behairy E. Behairy ${ }^{\mathrm{b}}$, Azza Abd El-Shaheed ${ }^{\mathrm{c}}$, Karam Mahdy ${ }^{\mathrm{d}}$, \\ Mohamed El-Batanony ${ }^{\mathrm{e}}$, Mohsen H. Hussein ${ }^{\mathrm{b}}$, Mostafa M. Sira ${ }^{\mathrm{b}, \mathrm{f}}$
}

\begin{abstract}
Background: The need for repetition of liver biopsy, especially in assessing the degree of fibrosis and follow-up of treatment protocols, justifies an intensive search for non-invasive alternatives. We attempted to investigate the clinical usefulness of serum fibrogenesis markers in pediatric chronic liver diseases.
\end{abstract}

Methods: We measured serum levels of TGF- $\beta 1$, collagen IV, laminin, MMP-2 and EGF-R, in 50 children with chronic liver disease (HBV, HCV and Bilharziasis) and 30 healthy controls, and determined their relationship to frequently used liver function tests and liver biopsy findings in patients.

Results: TGF- $\beta 1$, collagen IV, laminin and MMP-2, but not EGF$\mathrm{R}$, were significantly higher in patients than in controls $(\mathrm{P}<0.01)$. None of these markers correlated with the histological fibrosis stage, whereas laminin correlated with necroinflammatory activity $(\mathrm{P}<0.01)$. TGF- $\beta 1$, collagen IV, laminin and MMP-2 had the ability to discriminate patients with significant fibrosis, while only collagen IV and laminin were able to discriminate those with cirrhosis. Among these markers, collagen IV had the best predictive accuracy for significant fibrosis (AUROC 0.94; PPV 91.5\%) and cirrhosis (AUROC 0.85; PPV 80\%).

Manuscript accepted for publication November 22, 2010

${ }^{a}$ Department of Pediatrics, Faculty of Medicine, Ain Shams University, Cairo, Egypt

${ }^{\mathrm{b}}$ Department of Pediatric Hepatology, National Liver Institute, Menofiya University, 32511 Shebin El-koom, Menofiya, Egypt

${ }^{\mathrm{c}}$ Department of Child Health, National Research Centre, El Bohouth Street, Dokki 12311, Cairo, Egypt

${ }^{\mathrm{d}}$ Medical Biochemistry Department, National Research Centre, El

Bohouth Street, Dokki 12311, Cairo, Egypt

e Department of Pathology, National Liver Institute, Menofiya

University, 32511 Shebin El-koom, Menofiya, Egypt

${ }^{\mathrm{f}}$ Corresponding author: msira@liver-eg.org

doi:10.4021/gr246w
Conclusions: In conclusion, these markers may be useful in reducing but not replacing the need for liver biopsy in the monitoring of disease progression and treatment effectiveness and might be an inseparable part of assessment of chronic hepatopathies.

Keywords: Liver fibrosis; Hepatitis C virus; Hepatitis B virus; Bilharziasis; Collagen IV; Liver fibrosis; Egyptian children

\section{Introduction}

Hepatic fibrosis is the final common path of liver injury in most chronic liver diseases and can lead to cirrhosis, which is responsible for the majority of clinical complications. Liver biopsy is not only essential in establishing the diagnosis, but also in assessing the degree of fibrosis. Although liver biopsy has long been considered to be the gold standard of fibrosis assessment, the procedure is invasive, potentially associated with complications, and provides only a semi-quantitative assessment. Its repetition is required for following up the disease progression and monitoring treatment efficacy. This repetition is not easily accepted by patients especially in the pediatric population. Moreover, the diagnostic accuracy of liver biopsy in the staging of fibrosis is seriously affected by errors in sampling and inter-observer variation $[1,2]$. These drawbacks justify an intensive search for non-invasive alternatives that are safe, inexpensive and reliable [3]. Some serum markers have been described to correlate with liver fibrosis [4]. Non-invasive diagnosis of liver fibrosis has been extensively evaluated in adult populations [5-7]. In contrast, in pediatric population, data are lacking and liver biopsy is still the only reliable tool for diagnosing the histological features [8].

Fibrosis is characterized by excess deposition of extracellular matrix (ECM) components including different collagens and non-collagenous proteins such as laminin, fibronectin, undulin, and so on [9]. The key cellular mediator of fibrosis is the hepatic stellate cells (HSCs) which when activated serve as the primary collagen-producing cell. HSCs are activated by a variety of mechanisms, including cytokines, chemokines and others [10]. Activated HSCs release 
transforming growth factor-betal (TGF- $\beta 1$ ). This cytokine highly stimulates fibrogenesis by HSCs [11]. At the site of hepatic injury, damaged platelets release platelet derived growth factor and epidermal growth factor (EFG) which are strong stimulants for proliferation of HSCs [12]. There is continuous ECM deposition and degradation at the same time. Degradation is mediated by enzymes called matrix metalloproteinases (MMPs). In hepatic fibrosis, there is an increase in MMP-2 (collagenase IV or gelatinase A) leading to increased collagen IV destruction. Fibrosis mediators, enzymes and ECM breakdown products enter the circulation and thus potentially reflect fibrogenesis or fibrolysis [13].

The aim of this study was to evaluate the clinical benefits of serum markers of fibrosis in children with chronic liver disease (chronic viral hepatitis and Bilharziasis).

\section{Subjects and Methods}

\section{Study population}

Eighty children were enrolled in this study, 50 patients with chronic liver disease recruited from the National Liver Institute, Menofiya University, outpatient clinic and inpatient ward, and 30 apparently healthy children with no history or clinical evidence of liver disease or any other disease, attending the outpatient clinic for routine check-up, who served as controls. They were divided into four groups: chronic hepatitis $\mathrm{B}$ virus (HBV) group (12 patients), chronic hepatitis C virus (HCV) group (29 patients), Bilharziasis group (9 patients) and control group (30 children). A signed informed consent was obtained from the parents of all the patients and controls before enrollment in the study. The study was approved by the Research Ethics Committee of National Liver Institute, Menofiya University.

\section{Etiological diagnosis}

HBV infection was defined by positive hepatitis B surface antigen, hepatitis B core IgM or hepatitis B core IgG with liver biopsy features of HBV infection. HCV infection was defined by positive anti-HCV and detection of HCV-RNA by qualitative polymerase chain reaction (PCR). Bilharziasis was defined by positive rectal snip for bilharzial ova (8 patients) or passage of bilharzial ova in stool (1 patient) together with the presence of periportal fibrosis on liver ultrasound and absence of viral markers.

\section{Sample collection}

Blood samples were collected under complete aseptic technique from both patients and controls. Blood was allowed to clot naturally in the test tube, serum was then separated by centrifugation, divided into small aliquots and stored imme- diately at $-80^{\circ} \mathrm{C}$ till time of use. EDTA was added to a second sample for complete blood count (CBC) and was tested immediately. Na citrate was added to a third sample for assessing prothrombin concentration (PC).

\section{Liver biopsy}

Ultrasonography-guided liver biopsy was done for chronic hepatitis patients only. Liver biopsies were performed using true cut needle. Biopsy specimens were fixed in formalin and embedded in paraffin. Liver fibrosis and necroinflammatory activity were evaluated according to Ishak staging and grading score where histological activity index (HAI) ranged from 0 to 12 while fibrosis score ranged from F0 to F6 [14].

\section{Serum biochemical markers assay}

One aliquot was thawed and all individuals, patients and controls, were tested for liver function tests (LFTs) including total and direct bilirubin (TB and DB), aspartate transaminase (AST), alanine transaminase (ALT), alkaline phosphatase, gamma glutamyl transferase (GGT), total proteins, and serum albumin. The other aliquots were thawed and assayed for TGF- $\beta 1$, collagen IV, MMP-2, laminin and epidermal growth factor receptor (EGF-R). TGF- $\beta 1$ was measured by ELISA (DRG International Inc., USA) according to the method described by Kropf et al [15]. Collagen IV was measured by ELISA (Biotrin International LTD, Ireland) as described in Tsutsumi et al [16]. Total MMP-2 was measured using Quantikine immunoassay kit (R\&D systems, USA) according to the method of Murphy [17]. Laminin was measured by enzyme immunoassay kit (Takara, Japan) according to the method described by Burgeson et al [18]. EGF-R assayed by ELISA (Bender MedSystems, Austria) as described in Gamou and Schimizu [19].

\section{Statistical tools}

Descriptive results were expressed as mean \pm standard error of mean (mean $\pm \mathrm{SEM}$ ) or number (percentage) of individuals with a condition. Statistical significance between multiple groups was tested using non-parametric Kruskal-Wallis test. Significance between individual groups was tested either by nonparametric Mann-Whitney U test or Pearson's $\chi^{2}$ test. Correlations were tested by Spearman's correlation. The diagnostic value of serum biochemical markers was assessed by calculating the area under the receiver operator characteristic (ROC) curves. The diagnostic performance of the non-invasive markers for significant fibrosis and cirrhosis was measured as sensitivity, specificity, positive predictive value (PPV) and negative predictive value (NPV). Sensitivity, specificity, PPV and NPV were expressed as percentage. The cut-off values for optimal clinical performance were determined from the ROC curves. Results were considered 
Table 1. Demographic, Clinical and Laboratory Characteristics of the Studied Patients

\begin{tabular}{|c|c|c|c|c|c|}
\hline \multicolumn{2}{|c|}{ Characteristics } & \multirow{3}{*}{ 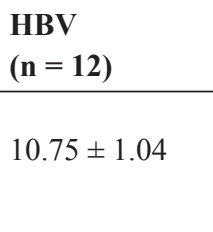 } & \multirow{3}{*}{ 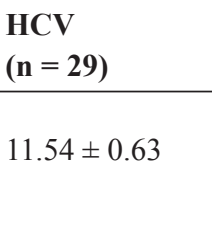 } & \multirow{3}{*}{ 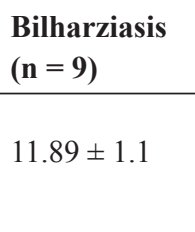 } & \multirow{3}{*}{$\begin{array}{l}\text { P-value } \\
0.206\end{array}$} \\
\hline Age (years) & Patients & & & & \\
\hline & Controls $10.5 \pm 0.46$ & & & & \\
\hline \multirow[t]{2}{*}{ Male n (\%) } & Patients & $10(83.3 \%)$ & $22(75.9 \%)$ & $9(100 \%)$ & 0.355 \\
\hline & Controls $22(73.3 \%)$ & & & & \\
\hline \multicolumn{2}{|c|}{ Hematemesis n (\%) } & $1(8.3 \%)$ & $4(13.8 \%)$ & $3(33.3 \%)$ & 0.267 \\
\hline \multicolumn{2}{|c|}{ Epistaxis n (\%) } & $1(8.3 \%)$ & $4(13.8 \%)$ & $2(22.2 \%)$ & 0.662 \\
\hline \multicolumn{2}{|c|}{ Hepatomegaly n (\%) } & $2(16.6 \%)$ & $8(27.6 \%)$ & $2(22.2 \%)$ & 0.751 \\
\hline \multicolumn{2}{|c|}{ Splenomegaly n (\%) } & $7(58.3 \%)$ & $19(56.5 \%)$ & $8(88.8 \%)$ & 0.301 \\
\hline \multicolumn{2}{|l|}{ Ascites n (\%) } & $2(16.6 \%)$ & $4(13.8 \%)$ & $3(33.3 \%)$ & 0.506 \\
\hline \multicolumn{2}{|l|}{$\mathrm{Hb}(\mathrm{g} / \mathrm{dl})$} & $10.5 \pm 0.42$ & $10.89 \pm 0.34$ & $11.18 \pm 0.39$ & 0.659 \\
\hline \multicolumn{2}{|c|}{ WBCs $\left(\mathrm{x} 10^{3} / \mathrm{mm}^{3}\right)$} & $6.38 \pm 0.95$ & $7.2 \pm 0.49$ & $7.04 \pm 0.67$ & 0.624 \\
\hline \multicolumn{2}{|c|}{ Platelets (x $\left.10^{3} / \mathrm{mm}^{3}\right)$} & $135.4 \pm 17.3$ & $161.9 \pm 14.1$ & $196.7 \pm 17.03$ & 0.64 \\
\hline \multicolumn{2}{|l|}{ TB (mg/dl) } & $1.83 \pm 0.22$ & $1.32 \pm 0.14$ & $0.95 \pm 0.16$ & $0.026^{*}$ \\
\hline \multicolumn{2}{|l|}{$\operatorname{ALT}(\mathrm{U} / \mathrm{L})$} & $72.58 \pm 12.41$ & $107.37 \pm 28.1$ & $30.67 \pm 3.21$ & $0.03 *$ \\
\hline \multicolumn{2}{|l|}{$\operatorname{AST}(\mathrm{U} / \mathrm{L})$} & $71.17 \pm 10.76$ & $120.07 \pm 21.78$ & $38.56 \pm 6.09$ & $0.002 * *$ \\
\hline \multicolumn{2}{|c|}{ Albumin (g/dl) } & $3.49 \pm 0.19$ & $3.57 \pm 0.11$ & $3.8 \pm 0.1$ & 0.35 \\
\hline \multicolumn{2}{|c|}{ Alkaline phosphatase (U/L) } & $214.33 \pm 41.18$ & $165.19 \pm 28.86$ & $80.33 \pm 12.42$ & $0.02 *$ \\
\hline \multicolumn{2}{|l|}{ GGT (U/L) } & $54.33 \pm 15.98$ & $59.87 \pm 11.06$ & $38.78 \pm 9.64$ & 0.61 \\
\hline \multicolumn{2}{|l|}{$\mathrm{PC}(\%)$} & $69.42 \pm 6.03$ & $65.61 \pm 2.46$ & $75.67 \pm 4.1$ & 0.163 \\
\hline
\end{tabular}

Quantitative data are expressed as mean \pm SEM and qualitative data as number and \%. Significance was tested using non-parametric Kruskal-Wallis test or Chi-square test. ${ }^{*} \mathrm{P} \leq 0.05,{ }^{* *} \mathrm{P} \leq 0.01$

significant if $\mathrm{P}$ value was no more than $0.05(* * \mathrm{P} \leq 0.01$; $* \mathrm{P} \leq 0.05)$. Statistical analysis was performed using SPSS software v.13.

\section{Results}

\section{Study individuals' characteristics}

Demographic, clinical and laboratory characteristics of the 80 studied individuals were described in Table 1. The patients and controls were age and sex matched $(\mathrm{P}>0.05$ for both) and there was a statistical significant difference between the studied groups as regards TB, ALT, AST and Alk. $\mathrm{Ph}$, while there were no significant differences as regards the other parameters.

\section{Serum levels of fibrosis markers in the studied groups}

Using Kruskal-Wallis test, there was a statistical significant difference among the four studied groups as regards TGF- $\beta 1$, collagen IV, laminin and MMP-2 ( $\mathrm{P}<0.000)$, while there was no significant difference as regards EGF-R (Table 2). When comparing the studied groups individually with each other (Fig. 1), TGF- $\beta$ and collagen IV were significantly higher in HBV, HCV and bilharzial group than in the control group with no significant difference between the three patients groups. Laminin in the HCV group was significantly higher than in the HBV and the control groups but not the Bilharziasis group; similarly, MMP-2 was significantly higher in HBV and HCV groups than in the controls but not in the Bilharziasis group. On the other hand, there was no significant difference between any of the studied groups as regards 
Table 2. Serum Levels of Biochemical Markers in the Studied Groups

\begin{tabular}{|c|c|c|c|c|c|c|c|}
\hline Marker & $\begin{array}{l}\text { HBV } \\
n=12\end{array}$ & $\begin{array}{l}\text { HCV } \\
n=29\end{array}$ & $\begin{array}{l}\text { Bilharziasis } \\
\mathbf{n}=\mathbf{9}\end{array}$ & $\begin{array}{l}\text { All Patients } \\
\mathbf{n}=\mathbf{5 0}\end{array}$ & $\begin{array}{l}\text { Controls } \\
\mathbf{n}=\mathbf{3 0}\end{array}$ & P-value ${ }^{a}$ & P-value ${ }^{b}$ \\
\hline TGF- $\beta 1$ (ng/ml) & $61.7 \pm 4.9$ & $68.7 \pm 2.6$ & $65.5 \pm 5.29$ & $66.504 \pm 2.14$ & $50.9 \pm 2.2$ & $0.000^{* *}$ & $0.000^{* *}$ \\
\hline EGF-R (ng/ml) & $0.904 \pm 0.1$ & $0.929 \pm 0.1$ & $1.2 \pm 0.19$ & $0.97 \pm 0.07$ & $0.88 \pm 0.05$ & 0.315 & 0.699 \\
\hline Collagen IV (ng/ml) & $211.1 \pm 19.4$ & $224.9 \pm 14.3$ & $226.1 \pm 29.5$ & $221.8 \pm 10.7$ & $85.6 \pm 3.6$ & $0.000 * *$ & $0.000 * *$ \\
\hline $\operatorname{Laminin}(\mathrm{ng} / \mathrm{ml})$ & $57.0 \pm 4.8$ & $68.9 \pm 2.5$ & $57.5 \pm 6.6$ & $64.05 \pm 2.3$ & $45.5 \pm 2.4$ & $0.000^{* *}$ & $0.000^{* *}$ \\
\hline MMP-2 (ng/ml) & $849.3 \pm 31.3$ & $787.6 \pm 33.6$ & $762.2 \pm 79.8$ & $797.87 \pm 25.18$ & $653.4 \pm 18.3$ & $0.000 * *$ & $0.000 * *$ \\
\hline
\end{tabular}

aSignificance was tested between all patients $(n=50)$ versus controls $(n=30)$ using Mann-Whitney test.

bSignificance was tested among individual etiological (HBV, HCV and Bilharziasis) groups and controls using Kruskal-

Wallis test.

${ }^{* *} \mathrm{P}<0.01$. Values are expressed as mean \pm standard error of mean $(\mathrm{SEM})$.

\section{A: TGF- $\beta 1$}

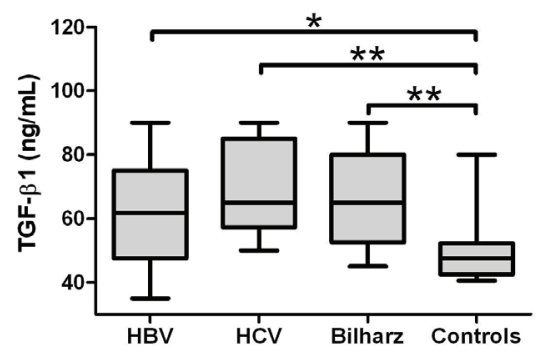

\section{C: Collagen IV}

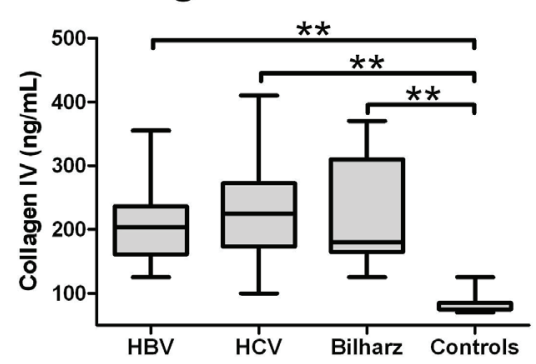

\section{B: EGFR}

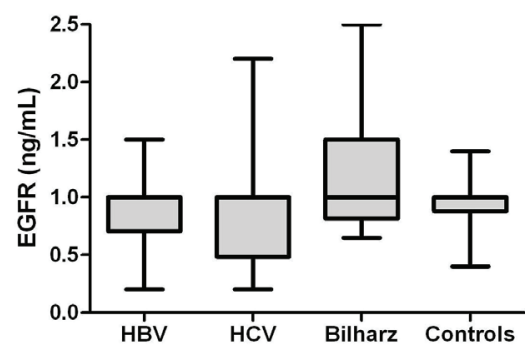

\section{D: Laminin}

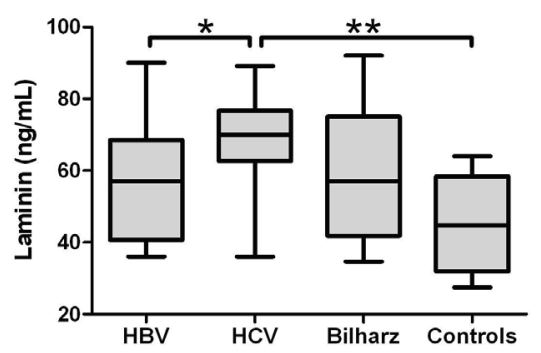

\section{E: MMP-2}

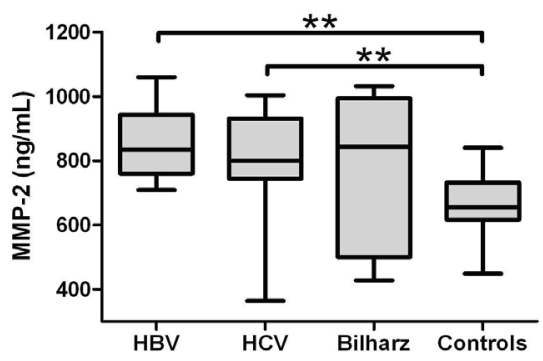

Figure 1. Box-and-whiskers plot for serum biochemical markers. The top and bottom of each box are the 25th and 75th centiles. The line through the box is the median and the error bars are the maximum and minimum. The horizontal bar represents the significance between the designated groups. ${ }^{*} \mathrm{P} \leq 0.05$ and ${ }^{* *} \mathrm{P} \leq 0.01$. 
Table 3. Correlation Analysis of Biochemical Markers With Age and Laboratory Parameters in All the Patients $(n=50)$ and With HAl and Stage of Fibrosis in Chronic Hepatitis B and C Patients Only $(n=19)$

\begin{tabular}{|c|c|c|c|c|c|c|}
\hline Variable & & TGF- $\beta 1$ & EGFR & Collage IV & Laminin & MMP-2 \\
\hline \multirow[t]{2}{*}{ EGFR } & $\mathrm{r}$ & -0.25 & & & & \\
\hline & $\mathrm{P}$ & 0.079 & & & & \\
\hline \multirow[t]{2}{*}{ Collage IV } & $\mathrm{r}$ & 0.126 & -0.156 & & & \\
\hline & $\mathrm{P}$ & 0.382 & 0.28 & & & \\
\hline \multirow[t]{2}{*}{ Laminin } & $\mathrm{r}$ & 0.024 & 0.034 & 0.205 & & \\
\hline & $\mathrm{P}$ & 0.867 & 0.817 & 0.153 & & \\
\hline \multirow[t]{2}{*}{ MMP-2 } & $\mathrm{r}$ & 0.116 & -0.030 & -0.018 & 0.048 & \\
\hline & $\mathrm{P}$ & 0.423 & 0.838 & 0.899 & 0.739 & \\
\hline \multirow[t]{2}{*}{ Age } & $\mathrm{r}$ & 0.02 & -0.122 & 0.202 & 0.044 & 0.103 \\
\hline & $\mathrm{P}$ & 0.892 & 0.397 & 0.159 & 0.761 & 0.475 \\
\hline \multirow[t]{2}{*}{ PLT } & $\mathrm{r}$ & 0.29 & 0.147 & 0.081 & 0.196 & 0.159 \\
\hline & $\mathrm{P}$ & $0.041 *$ & 0.308 & 0.574 & 0.172 & 0.27 \\
\hline \multirow[t]{2}{*}{ TBIL } & $\mathrm{r}$ & -0.063 & 0.109 & -0.053 & 0.093 & 0.068 \\
\hline & $\mathrm{P}$ & 0.663 & 0.451 & 0.716 & 0.52 & 0.637 \\
\hline \multirow[t]{2}{*}{ ALT } & $\mathrm{r}$ & -0.027 & -0.194 & 0.056 & 0.187 & 0.021 \\
\hline & $\mathrm{P}$ & 0.854 & 0.178 & 0.701 & 0.193 & 0.886 \\
\hline \multirow[t]{2}{*}{ AST } & $\mathrm{r}$ & -0.083 & -0.172 & 0.014 & 0.186 & -0.125 \\
\hline & $\mathrm{P}$ & 0.568 & 0.232 & 0.924 & 0.196 & 0.386 \\
\hline \multirow[t]{2}{*}{ Albumin } & $\mathrm{r}$ & 0.155 & 0.017 & 0.099 & -0.058 & 0.073 \\
\hline & $\mathrm{P}$ & 0.283 & 0.906 & 0.495 & 0.687 & 0.616 \\
\hline \multirow[t]{2}{*}{ ALP } & $r$ & 0.047 & -0.213 & -0.066 & 0.033 & 0.236 \\
\hline & $\mathrm{P}$ & 0.746 & 0.137 & 0.648 & 0.817 & 0.099 \\
\hline \multirow[t]{2}{*}{ GGT } & $\mathrm{r}$ & -0.06 & 0.011 & 0.123 & 0.104 & 0.075 \\
\hline & $\mathrm{P}$ & 0.68 & 0.941 & 0.395 & 0.474 & 0.607 \\
\hline \multirow[t]{2}{*}{ P.C } & $\mathrm{r}$ & 0.045 & 0.103 & 0.042 & -0.016 & 0.11 \\
\hline & $\mathrm{P}$ & 0.757 & 0.476 & 0.774 & 0.912 & 0.448 \\
\hline \multirow[t]{2}{*}{ HAI } & $\mathrm{r}$ & -0.226 & 0.117 & 0.138 & 0.636 & 0.072 \\
\hline & $\mathrm{P}$ & 0.351 & 0.635 & 0.573 & $0.003 * *$ & 0.769 \\
\hline \multirow{2}{*}{ Fibrosis stage } & $\mathrm{r}$ & -0.196 & 0.005 & -0.026 & -0.083 & -0.307 \\
\hline & $\mathrm{P}$ & 0.421 & 0.985 & 0.915 & 0.734 & 0.201 \\
\hline
\end{tabular}

$r=$ correlation coefficient, ${ }^{*} P \leq 0.05,{ }^{* *} P \leq 0.01$ 
Table 4. Diagnostic Performance of Serum Biochemical Markers in Predicting Significant Fibrosis and Cirrhosis in Chronic Hepatitis B and C Patients

\begin{tabular}{llllllll}
\hline Marker & AUROC & P-value & Cut-off & Sensitivity & Specificity & PPV & NPV \\
\hline \multicolumn{2}{l}{ Significant Fibrosis (Ishak score } & 2) & & & & & \\
TGF- $\beta 1$ & 0.74 & $0.01^{* *}$ & 54.8 & 78.6 & 71.4 & 73.3 & 76.9 \\
Collagen IV & 0.94 & $0.000^{* *}$ & 132.5 & 92.9 & 91.4 & 91.5 & 92.8 \\
Laminin & 0.82 & $0.001^{* *}$ & 60.9 & 71.4 & 77.1 & 75.7 & 72.9 \\
MMP-2 & 0.77 & $0.004^{* *}$ & 742 & 85.7 & 71.4 & 74.9 & 83.3 \\
Cirrhosis (Ishak score 6) & & & & & 72 & 82.3 \\
TGF- $\beta 1$ & 0.7 & 0.089 & 57.5 & 85.7 & 66.6 & 72 & 85.1 \\
Collagen IV & 0.85 & $0.003^{* *}$ & 147.5 & 85.7 & 78.6 & 80 & 73.9 \\
Laminin & 0.76 & $0.031^{*}$ & 63.7 & 71.4 & 81 & 78.9 \\
MMP-2 & 0.68 & 0.126 & 747 & 85.7 & 64.3 & 70 & 81.8 \\
\hline
\end{tabular}

${ }^{*} \mathrm{P} \leq 0.05,{ }^{* *} \mathrm{P} \leq 0.01$

EGFR, yet it was still higher in the Bilharziasis group than in the HBV, HCV and control groups.

Correlation of fibrosis biochemical markers with $\mathrm{CBC}$, LFTs in all the patients and with histopathological scores in chronic hepatitis $B$ and $C$ patients

Serum level of the five biochemical markers did not correlate with each other or with any of the LFTs or CBC components, except for TGF- $\beta 1$ which showed a significant positive correlation $(\mathrm{P}<0.05)$ with platelet count. Only 19 patients with chronic viral hepatitis had liver biopsy, but none of the bilharzial patients. Serum levels of the tested biochemical markers did not correlate with the stage of fibrosis or necroinflammatory activity, except for laminin which had significant direct correlation with necroinflammatory activity $(\mathrm{P}<$ 0.01) (Table 3).

\section{Diagnostic performance of fibrosis biochemical markers for discriminating significant fibrosis and cirrhosis}

Considering that significant fibrosis equals Ishak score more than 2 and cirrhosis equals Ishak score 6 [20], we estimated the area under the ROC curve (AUROC), the sensitivity, specificity, PPV, NPV and cut off values identifying individuals with significant fibrosis and those with cirrhosis (Fig. 2 and Table 4). TGF- $\beta 1$ more than $54.8 \mathrm{ng} / \mathrm{ml}$ had a sensitivity of $78.6 \%$ and specificity of $71.4 \%$ in identifying significant fibrosis (Fig. 2A), and TGF- $\beta 1$ more than $57.5 \mathrm{ng} / \mathrm{ml}$ had a sensitivity of $85.7 \%$ and specificity of $66.6 \%$ in identifying cirrhosis. Collagen IV at a cut off value of no less than 132.5 $\mathrm{ng} / \mathrm{ml}$ had a sensitivity of $92.9 \%$ and specificity of $91.4 \%$ identifying significant fibrosis (Fig. 2B) and at a cut off value of more than $147.5 \mathrm{ng} / \mathrm{ml}$ had a sensitivity of $85.7 \%$ and specificity of $78.6 \%$ in identifying cirrhosis. Laminin at a cut off value of more than $60.9 \mathrm{ng} / \mathrm{ml}$ had a sensitivity of $71.4 \%$ and specificity of $77.1 \%$ in identifying significant fibrosis (Fig. 2C) and at a cut off value of more than $63.7 \mathrm{ng} /$ $\mathrm{ml}$ had a sensitivity of $71.4 \%$ and specificity of $81 \%$ in identifying cirrhosis. MMP-2 at a cut off value of more than 742 $\mathrm{ng} / \mathrm{ml}$ has a sensitivity of $85.7 \%$ and specificity of $71.4 \%$ in identifying significant fibrosis (Fig. 2D) and at a cut off value of more than $747 \mathrm{ng} / \mathrm{ml}$ had a sensitivity of $85.7 \%$ and specificity of $64.6 \%$ in identifying cirrhosis. Using different combinations of TGF- $\beta 1$, Collagen, laminin and MMP 2 did not significantly increase the performance over the use of each marker alone.

\section{Discussion}

The aim of the present study was to evaluate the clinical benefits of serum biomarkers of liver fibrosis in pediatric chronic liver diseases. For this purpose, we employed five serum biological markers (TGF- $\beta 1$, collagen IV, MMP-2, laminin and EGF-R) which are assumed to reflect the degree of liver fibrosis and compared these markers in 50 pediatric patients with chronic liver diseases to 30 healthy controls. Of these markers, TGF- $\beta 1$, collagen IV, laminin and MMP-2 were significantly higher in diseased than in healthy 

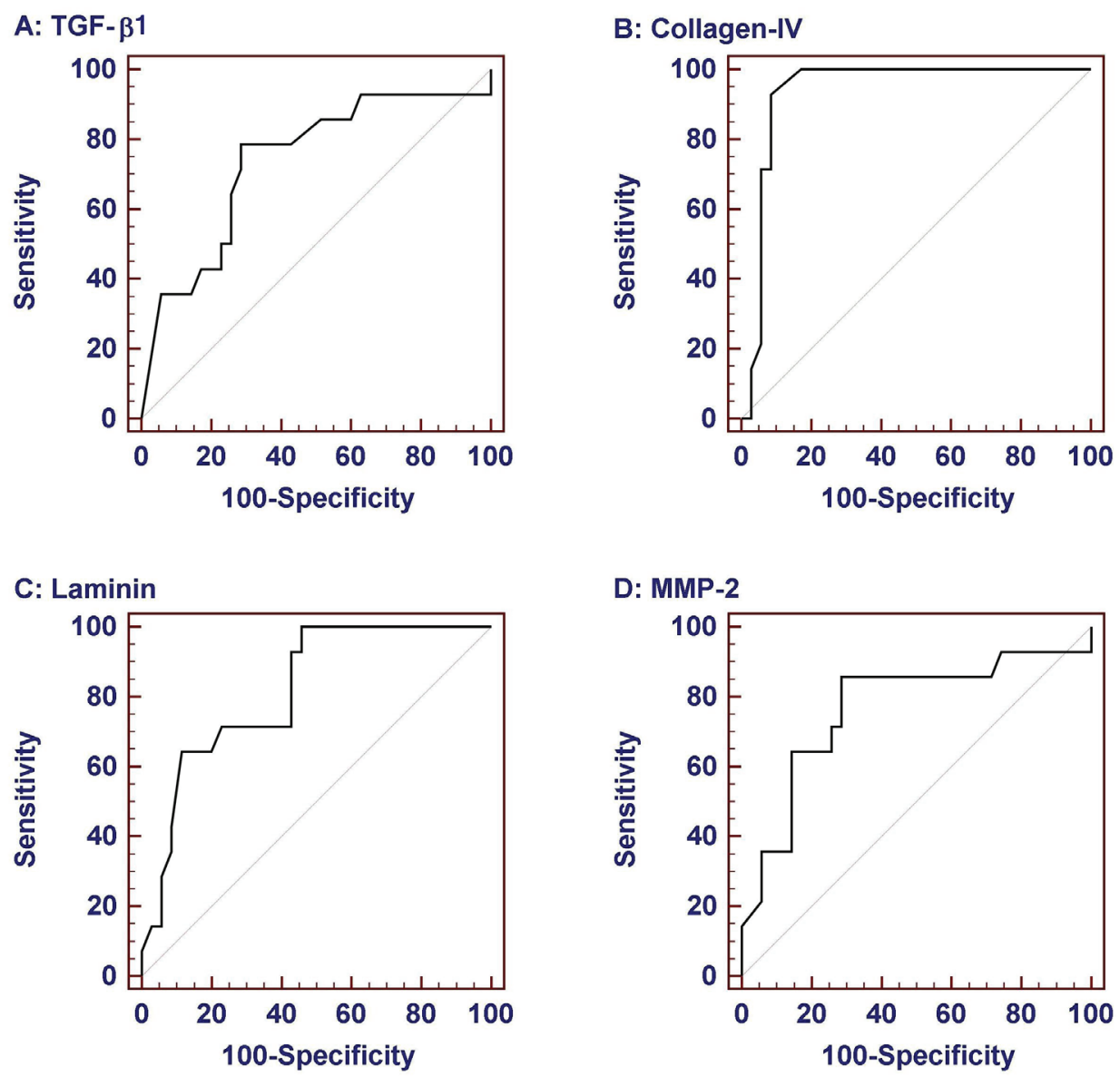

Figure 2. Receiver-operator characteristic (ROC) curves of serum biochemical markers for prediction of significant fibrosis (Ishak score > 2). Data were analyzed considering patients with liver biopsy in the chronic hepatitis group. Among them collagen IV was the most sensitive and specific.

controls. Comparing individual etiologic groups to controls, biochemical markers had the same significance in HCV and HBV patients. This significant elevation might reflect the fibrogenic process in the liver.

In the normal liver, sinusoidal endothelial cells and Kupffer cells have relatively high constitutive levels of TGF- $\beta 1$, whereas HSCs express very little TGF- $\beta 1$ in the normal state, and hepatocytes essentially none. When injury strikes, inflammatory cells are drawn to the site of injury and HSCs undergo activation, becoming myofibroblasts, which migrate, proliferate and become fibrogenic and contractile. This is due to TGF- $\beta 1$ upregulation, increased activation, and increased receptor expression and signaling components $[21,22]$. Luo et al found a significant elevation of TGF- $\beta 1$ in liver cirrhosis, yet its correlation with activity was moderate [23]. In our study, TGF- $\beta 1$ did not correlate with disease activity or with stage of liver fibrosis. In accordance with our results, Yang et al reported that TGF- $\beta 1$ did not correlate to the severity of liver disease [24]. On the other hand, Zhang et al found that the level of TGF- $\beta 1$ in chronic liver disease was comparable to that of the control group [25]. Our results showed that TGF- $\beta 1$ significantly correlated with platelet count. This finding is explained by the fact that platelets are a major source of TGF- $\beta 1$; moreover, platelets play a role in activation of its latent form [26].

Although it was reported that the expression of EGF and its receptor increase in cirrhosis and in viral liver disease $[12,27]$, we found that levels of EGF-R were comparable in $\mathrm{HBV}, \mathrm{HCV}$, bilharziasis and the controls. Yet, it was still higher in the bilharziasis group than in the other three studied groups. Abdel Rahman et al reported that EGF, which is the ligand for EGF-R, was indirectly stimulated by the bilharzial infection [27]. This may lead to EGF-R upregulation. Another possibility is that Schistosoma mansoni gene encodes a homologue of human EGF-R. This gene sequence has been characterized and found to encode a protein which shares substantial sequence and structural homology with other members of the EGF-R family [28, 29]. In our study, 
bilharzial patients were of mansoni type. This would explain the higher level of EGF-R in this group compared to HBV, $\mathrm{HCV}$ and control groups.

Similar to our results, Friedman et al and others [11, 30, 31 ] found that serum levels of collagen IV and laminin were significantly higher in patients with hepatic disorders than in healthy controls. Although in our study, laminin was found to be the only marker that highly correlates with HAI $(\mathrm{P}<$ $0.01)$ in the viral group, Lu et al [32] reported that laminin has no diagnostic value either in inflammation or in fibrotic changes in patients with chronic liver disease.

In agreement with our results, Kasahara et al and Walsh et al found that serum levels of MMP-2 were elevated in patients than in controls $[33,34]$. On the other hand, Boeker et al [35] and Mueawaki et al [36] reported that serum MMP-2 concentrations were not altered in chronic liver disease. Taking the etiology into consideration, we could demonstrate that patients with viral etiology had significantly higher serum MMP-2 levels than the controls, whereas in patients with bilharziasis, the serum level of MMP-2 was comparable to that of the controls.

Paduch and Kandefer-Szerszen [37] demonstrated the inhibitory effect of vitamin D on MMP2. Furthermore, the addition of vitamin $\mathrm{D}$ to neoplastic cell cultures suppressed MMP2 secretion. Timms et al [38] have shown vitamin D deficiency to be associated with significant increase in MMP2. Arteh et al [39] and Goerge et al [40] reported vitamin D deficiency in chronic hepatitis B and C where lower levels were found in patients with liver cirrhosis than in non-cirrhotics. Moreover, Petta et al [41] demonstrated that vitamin D serum levels were significantly lower in chronic hepatitis C genotype 1 than in the controls and lower levels were associated with increasing stage of fibrosis and necroinflammatory activity. Moreover, it has been shown that vitamin D protects against oxidative stress and reduces the inflammatory and fibrogenic activity of liver stellate cells. Gibney et al [42] studied vitamin D deficiency in different infectious disorders. Bilharziasis was found not to be associated with vitamin D deficiency. Taken together, this may explain the significant increase of MMP2 in chronic hepatitis B and C compared to bilharziasis and the controls group. In other words, MMP2 increased in chronic hepatitis B and C due to the proposed associated vitamin D deficiency in such patients. On the other hand, MMP2 level in Bilharziasis group was comparable to the controls as this type of infection is not associated with vitamin $\mathrm{D}$ deficiency. Worth to mention that the pattern of serum biochemical markers of fibrosis differs according to the etiology of the chronic liver diseases and markers that might be of significance in certain diseases might not be in others.

Except for EGF-R which showed no statistical significant change among the studied groups, TGF- $\beta 1$, collagen IV, laminin and MMP-2 had the ability, within acceptable performance, to discriminate patients with significant fibrosis (namely $\mathrm{F}>2$ ), while only collagen IV and laminin were able to discriminate those with cirrhosis in chronic hepatitis B and C patients. Collagen IV at a cut-off value of 132 $\mathrm{ng} / \mathrm{ml}$ performed better than the other markers in identifying significant fibrosis and cirrhosis. Murawaki et al found that serum collagen IV can be used as a diagnostic aid for the detection of liver fibrosis at a cut-off value of $110 \mathrm{ng} / \mathrm{ml}$ with sensitivity $75 \%$ [43].

In conclusion, TGF- $\beta 1$, collagen IV, laminin and MMP2 may be used to predict significant fibrosis and/or cirrhosis in children with chronic hepatitis B and C. Among them, collagen IV was the most sensitive and specific. That is to say, non-invasive markers will likely reduce but not replace the need for liver biopsy, which may be useful in monitoring of disease development and treatment effectiveness and might be an inseparable part of assessment of chronic hepatopathies.

\section{Financial Support}

This study was funded by the National Research Centre, Dokki, Cairo, Egypt. Research projects 5/4/5 and 5/5/5, in collaboration with the National Liver Institute, Menofiya University, Egypt.

\section{Conflict of Interest}

The authors declare that there is no conflict of interest.

\section{References}

1. Fontana RJ, Goodman ZD, Dienstag JL, Bonkovsky HL, Naishadham D, Sterling RK, Su GL, et al. Relationship of serum fibrosis markers with liver fibrosis stage and collagen content in patients with advanced chronic hepatitis C. Hepatology 2008;47(3):789-798.

2. White IR, Patel K, Symonds WT, Dev A, Griffin P, Tsokanas N, Skehel M, et al. Serum proteomic analysis focused on fibrosis in patients with hepatitis $\mathrm{C}$ virus infection. J Transl Med 2007;5:33.

3. Rockey DC, Bissell DM. Noninvasive measures of liver fibrosis. Hepatology 2006;43(2 Suppl 1):S113-120.

4. Leroy V, Hilleret MN, Sturm N, Trocme C, Renversez JC, Faure P, Morel F, et al. Prospective comparison of six non-invasive scores for the diagnosis of liver fibrosis in chronic hepatitis C. J Hepatol 2007;46(5):775-782.

5. Poynard T. Treatment of cirrhotic patients in the pegylated interferon era. Dig Liver Dis 2004;36 (Suppl 3):S344-348.

6. Sebastiani G, Vario A, Guido M, Alberti A. Sequential algorithms combining non-invasive markers and biopsy 
for the assessment of liver fibrosis in chronic hepatitis B. World J Gastroenterol 2007;13(4):525-531.

7. Sebastiani G, Vario A, Guido M, Noventa F, Plebani M, Pistis R, Ferrari A, et al. Stepwise combination algorithms of non-invasive markers to diagnose significant fibrosis in chronic hepatitis C. J Hepatol 2006;44(4):686693.

8. Iacobellis A, Marcellini M, Andriulli A, Perri F, Leandro G, Devito R, Nobili V. Non invasive evaluation of liver fibrosis in paediatric patients with nonalcoholic steatohepatitis. World J Gastroenterol 2006;12(48):78217825.

9. Bolarin DM, Azinge EC. Biochemical markers, extracellular components in liver fibrosis and cirrhosis. Nig Q J Hosp Med 2007;17(1):42-52.

10. Wynn T. Cellular and molecular mechanisms of fibrosis. J Pathol 2008;214(2):199-210.

11. Friedman SL. Molecular regulation of hepatic fibrosis, an integrated cellular response to tissue injury. J Biol Chem 2000;275(4):2247-2250.

12. Komuves LG, Feren A, Jones AL, Fodor E. Expression of epidermal growth factor and its receptor in cirrhotic liver disease. J Histochem Cytochem 2000;48(6):821830 .

13. Lichtinghagen R, Huegel O, Seifert T, Haberkorn CI, Michels D, Flemming P, Bahr M, et al. Expression of matrix metalloproteinase-2 and -9 and their inhibitors in peripheral blood cells of patients with chronic hepatitis C. Clin Chem 2000;46(2):183-192.

14. Ishak K, Baptista A, Bianchi L, Callea F, De Groote J, Gudat F, Denk H, et al. Histological grading and staging of chronic hepatitis. J Hepatol 1995;22(6):696-699.

15. Kropf J, Schurek JO, Wollner A, Gressner AM. Immunological measurement of transforming growth factorbeta 1 (TGF-beta1) in blood; assay development and comparison. Clin Chem 1997;43(10):1965-1974.

16. Tsutsumi M, Urashima S, Matsuda Y, Takase S, Takada A. Changes in type IV collagen content in livers of patients with alcoholic liver disease. Hepatology 1993;17(5):820-827.

17. Murphy G. In Handbook of Proteolytic Enzymes. Barrett A.J. et al., eds., Academic Press, San Diego 1998:11991205.

18. Burgeson RE, Chiquet M, Deutzmann R, Ekblom P, Engel J, Kleinman H, Martin GR, et al. A new nomenclature for the laminins. Matrix Biol 1994;14(3):209-211.

19. Gamou S, Shimizu N. Hydrogen peroxide preferentially enhances the tyrosine phosphorylation of epidermal growth factor receptor. FEBS Lett 1995;357(2):161164.

20. Fabris C, Smirne C, Toniutto P, Colletta C, Rapetti R, Minisini R, Falleti E, et al. Assessment of liver fibrosis progression in patients with chronic hepatitis $\mathrm{C}$ and normal alanine aminotransferase values: the role of AST to the platelet ratio index. Clin Biochem 2006;39(4):339343.

21. Bissell DM, Roulot D, George J. Transforming growth factor beta and the liver. Hepatology 2001;34(5):859867.

22. Safadi R, Friedman SL. Hepatic fibrosis--role of hepatic stellate cell activation. MedGenMed 2002;4(3):27.

23. Luo R, Yang S, Xie J, Zhao Z, He Y, Yao J. [Diagnostic value of five serum markers for liver fibrosis]. Zhonghua Gan Zang Bing Za Zhi 2001;9(3):148-150.

24. Yang L, Liu X, Fu H, Qiang O, Huang M. [TGF beta 1 and ET-1 expression in the peripheral blood of patients with cirrhosis]. Hua Xi Yi Ke Da Xue Xue Bao 2001;32(2):202-203, 212.

25. Zhang BB, Cai WM, Weng HL, Hu ZR, Lu J, Zheng M, Liu RH. Diagnostic value of platelet derived growth factor-BB, transforming growth factor-beta1, matrix metalloproteinase-1, and tissue inhibitor of matrix metalloproteinase- 1 in serum and peripheral blood mononuclear cells for hepatic fibrosis. World J Gastroenterol 2003;9(11):2490-2496.

26. Blakytny R, Ludlow A, Martin GE, Ireland G, Lund LR, Ferguson MW, Brunner G. Latent TGF-beta1 activation by platelets. J Cell Physiol 2004;199(1):67-76.

27. Abdel Rahman M, Eid SA, Abdel Rahman A, Nasr G, Morsy TA. Epidermal growth factor in patients with schistosomal and/or viral liver diseases and portal hypertension. J Egypt Soc Parasitol 2000;30(1):233-243.

28. Ramachandran H, Skelly PJ, Shoemaker CB. The Schistosoma mansoni epidermal growth factor receptor homologue, SER, has tyrosine kinase activity and is localized in adult muscle. Mol Biochem Parasitol 1996;83(1):110 .

29. Shoemaker CB, Ramachandran H, Landa A, dos Reis MG, Stein LD. Alternative splicing of the Schistosoma mansoni gene encoding a homologue of epidermal growth factor receptor. Mol Biochem Parasitol 1992;53(1-2):17-32.

30. Szantova M, Kupcova V. [Biochemical markers of fibrogenesis in liver diseases]. Bratisl Lek Listy 1999;100(1):28-35.

31. Yokoya Y, Iwata K, Muragaki Y, Shiota C, Morimoto Y, Inoue $\mathrm{M}$, Itoh $\mathrm{H}$, et al. Concentration of serum laminin and type IV collagen in liver diseases assayed by a sandwich enzyme-immunoassay using monoclonal antibodies. Clin Chim Acta 1992;210(1-2):109-118.

32. Lu LG, Zeng MD, Wan MB, Li CZ, Mao YM, Li JQ, Qiu DK, et al. Grading and staging of hepatic fibrosis, and its relationship with noninvasive diagnostic parameters. World J Gastroenterol 2003;9(11):2574-2578.

33. Kasahara A, Hayashi N, Mochizuki K, Oshita M, Katayama K, Kato M, Masuzawa M, et al. Circulating matrix metalloproteinase-2 and tissue inhibitor of metalloproteinase- 1 as serum markers of fibrosis in patients with 
chronic hepatitis C. Relationship to interferon response. J Hepatol 1997;26(3):574-583.

34. Walsh KM, Timms P, Campbell S, MacSween RN, Morris AJ. Plasma levels of matrix metalloproteinase-2 (MMP-2) and tissue inhibitors of metalloproteinases -1 and -2 (TIMP-1 and TIMP-2) as noninvasive markers of liver disease in chronic hepatitis $\mathrm{C}$ : comparison using ROC analysis. Dig Dis Sci 1999;44(3):624-630.

35. Boeker KH, Haberkorn CI, Michels D, Flemming P, Manns MP, Lichtinghagen R. Diagnostic potential of circulating TIMP-1 and MMP-2 as markers of liver fibrosis in patients with chronic hepatitis C. Clin Chim Acta 2002;316(1-2):71-81.

36. Murawaki Y, Ikuta Y, Koda M, Okamoto K, Mimura K. The proMMP-2 activation rate in patients with chronic viral liver disease. Clin Chim Acta 2002;324(1-2):99103.

37. Paduch R, Kandefer-Szerszen M. Vitamin D, tamoxifen and beta-estradiol modulate breast cancer cell growth and interleukin- 6 and metalloproteinase- 2 production in three-dimensional co-cultures of tumor cell spheroids with endothelium. Cell Biol Toxicol 2005;21(5-6):247256.

38. Timms PM, Mannan N, Hitman GA, Noonan K, Mills PG, Syndercombe-Court D, Aganna E, et al. Circulating
MMP9, vitamin D and variation in the TIMP-1 response with VDR genotype: mechanisms for inflammatory damage in chronic disorders? Qjm 2002;95(12):787796.

39. Arteh J, Narra S, Nair S. Prevalence of Vitamin D Deficiency in Chronic Liver Disease. Dig Dis Sci 2009.

40. George J, Ganesh HK, Acharya S, Bandgar TR, Shivane V, Karvat A, Bhatia SJ, et al. Bone mineral density and disorders of mineral metabolism in chronic liver disease. World J Gastroenterol 2009;15(28):3516-3522.

41. Petta S, Camma C, Scazzone C, Tripodo C, Di Marco $\mathrm{V}$, Bono A, Cabibi D, et al. Low vitamin D serum level is related to severe fibrosis and low responsiveness to interferon-based therapy in genotype 1 chronic hepatitis C. Hepatology 2005;51(4):1158-1167.

42. Gibney KB, Mihrshahi S, Torresi J, Marshall C, Leder $\mathrm{K}$, Biggs BA. The profile of health problems in African immigrants attending an infectious disease unit in Melbourne, Australia. Am J Trop Med Hyg 2009;80(5):805811.

43. Murawaki Y, Koda M, Okamoto K, Mimura K, Kawasaki H. Diagnostic value of serum type IV collagen test in comparison with platelet count for predicting the fibrotic stage in patients with chronic hepatitis C. J Gastroenterol Hepatol 2001;16(7):777-781. 